\title{
Remaking the Chinese Administrative State Since 1978: The Double-Movements Perspective
}

\author{
Jun Ma* and Zhibin Zhang**
}

\begin{abstract}
This paper examines the fundamental logic that shaped the Chinese administrative reforms during the past three decades from the perspective of the "double movements": marketization and self-protection of society. It is contended while the rebuilding of the Chinese administrative state, up until the end of the 1990s, was mainly driven by the single movement of marketization, with its focus on reforming the government to accommodating to the development of a modern market economy, it now has to respond to the countermovement of selfprotection of society which demands the government to meet social needs and preserve social values. However, as the two movements hold different goals and move in opposite directions, administrative reforms from now on must be carried out in the tension of the double movements, which is a demanding challenge.
\end{abstract}

Keywords: Chinese Administrative Reform, Dynamics, Double Movements, Marketization, Self-protection of Society

\section{INTRODUCTION}

The years since 1980 have witnessed a remarkable movement worldwide to reform public administration. For many (for example, Kettl 2005), there is a striking international convergence of ideas among these administrative reforms, while others disagree

* Jun $\mathrm{Ma}(\mathrm{Ph}$. D., University of Nebraska at Omaha) is a professor, director of the Center for Public Administration Research (CPAR) and associate dean of the School of Government, Sun Yat-sen University. He is also a chief editor of the Journal of Public Administration, People's Republic of China. His researches focus on public administration and public budgeting, and his publications appeared in academic journals of China, USA, UK, and Australia. Email: majun@mail.sysu.edu.cn. This research is funded by the CPAR project 06JJD6300.

** Zhibin Zhang(Ph. D., George Washington University) is an assistant professor of public administration, School of Humanities \&Social Sciences, Nanyang Technological University, Singapore. His research interests lie in public administration and NGOs, and his publications appeared in academic journals of China and USA. Email: ZZB@ntu.edu.sg.

Manuscript received November 2008; out for review February 2009; review completed February 2009; accepted February 2009.

The Korean Journal of Policy Studies, Vol. 23, No. 2, 225-252 (2009)

(C) 2009 by the GSPA, Seoul National University 
(Manning \& Parison 2003). Despite these different stances, the international debate on administrative reforms has been overly influenced by the so-called New Public Management (NPM). In this context, the administrative reforms in China were also conceptualized as a variation of NPM with nonwestern characteristics (Worthley \& Tsao 1999). But attempts to force China's administrative reforms to fit the mold of NPM are inevitably misleading (see also Chan \& Chow 2007; Ngok \& Zhu 2007; K. Yang 2004) because they overlook the uniqueness of the Chinese situation. If China's administrative reforms do not fit the NPM model, how can they best be understood? This paper seeks to go beyond the NPM discourse to examine China's administrative reforms since the 1978 economic reform from their own logic and distinctive historical background.

The Chinese administrative state has been transformed significantly since the economic reform. These reforms, particularly the civil service reforms and bureaucratic reorganizations, have been well documented and assessed in both the Chinese and English literature (Brødsgaard 2002; Burns 1993a, 1993b, 2001, 2003, 2007; Chan \& Li 2007; Lan 1999; Tsao \& Worthley 1995; Worthley \& Tsao 1999). However, no theoretical framework has been developed to examine the fundamental logic or the inherent dynamics underlying all these administrative reforms as a whole. Consequently, some critical issues about China's thirty-year reforms remain ambiguous: What has been the focus of China's administrative reforms at different stages? What has been achieved; what has been neglected; and what challenges lie ahead?

Recently, two studies attempted to fill up this gap by exploring the intrinsic logic underlying Chinese administrative reforms. Yang $(2001$; 2004) argued that administrative reforms in China are a process in which the government has been continually rationalized in order to cater to the demands of developing a market economy. Viewing from a similar but wider perspective taking into account China's entry into the global market, Ngok and Zhu (2007) came to a similar conclusion while pointing out challenges ahead. These two studies represent a new direction in the examination of Chinese administrative reforms, adopting a holistic framework to comprehend the fundamental dynamics that have driven these reforms and their resulting features. Notwithstanding these achievements, these studies are not without limitations. For them, marketization is the sole logic driving the Chinese administrative reforms. In fact, it can be argued that marketization is just one dimension of the dynamics of Chinese state rebuilding since the 1978 economic reform (Ma 2008; Wang 2007).

In order to gain a more complete understanding of China's administrative reforms, particularly their underlying logic, a broader theoretical framework is desirable, which is the goal of this paper. Our theoretical framework borrows heavily from Karl Polanyi's ([1944] 1957) still stimulating work, The Great Transformation, particularly his con- 
cept of the double movements of marketization and self-protection of society. The central theme of this paper is that the tension between these two movements has increasingly driven and shaped Chinese administrative reforms. Until the end of 1990s, reforms were mainly driven by market liberalism, in order to establish a market economy out of a centrally planned economy. Once that market economy gained ground, beginning in the late 1990s, market liberalism remained an important force, but the self-protection of society, an opposite force to market liberalism, began increasingly to exert its influence on the Chinese administrative reforms and to redefine reform priorities. From then on, the remaking of the Chinese administrative state has been defined by the tension between these two movements, which can explain the essential characteristics of more recent reforms. This framework is expected to enable us to grasp the dynamics and complexities of China's administrative reforms as well as the nature of challenges ahead in remaking the Chinese administrative state.

The next section of the paper will present this theoretical framework in more detail. Following sections will first examine the early administrative reforms, primarily driven by marketization, and then more recent reforms, mainly driven by the self-protection of society, and look at the challenges ahead. The final section offers a conclusion and discussion.

\section{THEORETICAL FRAMEWORK}

China in the Mao era was a totalitarian state that, through abolishing the market system and implementing tight social controls, not only destroyed all interest groups in the economic and public spheres, but also penetrated deeply into the private sphere. With the initiation of economic reform in 1978, the central planning system was incrementally replaced by a market economy. The private sector expanded and eventually outstripped state-owned enterprises (SOEs) in total production and rates of growth (Dickson \& Chao 2001). Also, the scope of state control over both the public and private spheres shrank significantly (White, Howell, \& Shang 1996).

In this process of economic liberalization, the administrative system created under the centrally planned economy was reformed to accommodate a modern market economy. Up to the late 1990s, therefore, the major driving force of China's administrative reforms was marketization, which was guided by a Chinese version of market liberalism based on the concept of the self-regulating market and the belief that a free, liberal, and unfettered market would generate unprecedented material welfare and individual freedom. In this circumstance, the goal of China's administrative reforms was to allow the government's excessive intervention in the economy to wither and to let the 
market be the main mechanism of resource allocation (Ngok \& Zhu 2007; White et al. 1996; Yang 2001). In other words, the Chinese administrative reforms until the end of the 1990s aimed to subordinate government functions to the logic of the market. The Chinese experience illustrates the point made by Polanyi ([1944] 1957, 250) that the emergence of a free market "has been the outcome of a conscious and often violent intervention on the part of government which imposed the market organization on society."

Although a self-regulating market might produce unparalleled material welfare, its operation would always result in astonishing negative social and environmental consequences, especially when the government completely follows the liberal creed of minimal state intervention (Polanyi [1944] 1957). According to Polanyi ([1944] 1957, 3), the self-regulating market, if left to operate unchecked, "would have physically destroyed man and transformed his surroundings into a wilderness." But inevitably, society would take measures to protect itself, and marketization would encounter a countermovement, namely the self-protection of society, that would check its expansion. Self-protection of society "was more than the usual defensive behavior of a society faced with change; it was a reaction against a dislocation which attacked the fabric of society, and which would have destroyed the very organizations of production that the market had called into being," Polyani said (136). And this movement would pressure the government to reform its governing structure from an opposite direction.

In the case of China, beginning in 1978, marketization became the major driving force for administrative reforms. The Chinese state gradually transformed and gave way to the unfettered market, which contributed to perhaps the longest period of rapid economic growth in human history. Nevertheless, since the mid-1990s, the dark side of the dominant marketization movement has begun to unfold itself: widened income inequality, the rise of urban poverty, the exploitation of the labor, poisoned food and drugs, pervasive corruption, environmental deterioration, and other problems.

As a response, various efforts emerged to protect society from the dangers of an unfettered market. Recently, the movement toward self-protection of society has increased in strength, magnitude, scale, and extent. By the late 1990s, it had become so powerful that it influenced the Chinese government, previously obsessed with market-driven rationalization, to redefine its reform agenda and realize that if societal demands were neglected, the source of its legitimacy would be undermined. Consequently, the Chinese government has adopted a series of reform measures since the late 1990 s to check the excessive expansion of the market and rescue society and the environment from the "satanic mills" of the market economy.

Marketization remained, of course, an important force propelling Chinese administrative reforms toward rationalization, and building a modern market economy to main- 
tain rapid economic growth remained the ruling party's long-term strategic goal. Starting in the late 1990s, therefore, administrative reforms in China were pulled simultaneously in two opposite directions: marketization and self-protection of society.

Figure 1. The Driving Forces of Chinese Administrative Reform

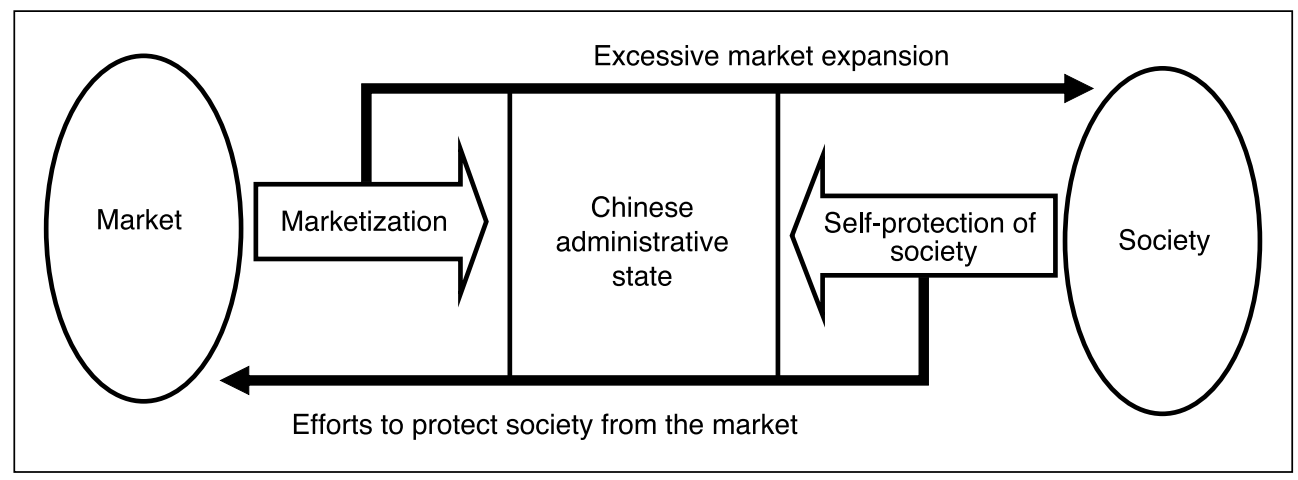

In summary, while the rebuilding of the Chinese administrative state, up until the end of the 1990s, was mainly driven by the single movement of marketization, with its focus on limiting the scope of the government in the market, it now has to find a balance between marketization and the countermovement of societal self-protection. As the two movements hold different goals and move in opposite directions, administrative reforms must now be carried out in the tension of these double movements-a demanding challenge. Figure 2 illustrates the dynamics of the driving forces of China's thirty year administrative reform.

\section{ADMINISTRATIVE REFORMS DRIVEN BY MARKETIZATION}

In contrast to the "shock therapy" strategies that prevailed in the former Soviet Union and Eastern Europe during their economic transition, Chinese economic reform has been more gradual. Having successfully built momentum in the agrarian sector between 1978 and 1983, China then began to adopt far-reaching urban economic reform in 1984. Incrementally but steadily, economic reform advanced toward marketization. In 1993, the Third Plenum of the Fourteenth Chinese Communist Party (CCP) Central Committee announced that the ultimate goal of economic reform was to build up a "socialist market economy." After that, economic liberalization accelerated. By the late 1990s, the cumulative impact of economic reform had radically changed the landscape and the operation of the Chinese economy (Dickson \& Chao 
2001). When the reform commenced in 1978, for instance, 77.6 percent of gross industrial output was produced by state-owned enterprises, but in 1998 the share dropped to 28.5 percent. With the gradual disintegration of central planning, the market became the determining force in most areas of the Chinese economy (Wang 2004).

According to measurements by $\mathrm{Chen}, \mathrm{Wu}$, and $\mathrm{Xie}$ (2000) in eight sectors, the degree of marketization in China has significantly increased, as shown in table 1.

Table 1. Degree of Marketization (\%) in Different Sectors, 1978-1997

\begin{tabular}{l|c|c|c|c|c|c|c|c|c}
\hline & 1978 & 1984 & 1988 & 1990 & 1992 & 1993 & 1994 & 1995 & 1997 \\
\hline Enterprises & 0.0 & 10.0 & 23.0 & 15.0 & 25.0 & 34.7 & 40.0 & 46.4 & 48.0 \\
Government behavior & 4.0 & 51.0 & 63.3 & 62.2 & 66.6 & 71.7 & 72.0 & 73.0 & 72.0 \\
Commodity prices & 2.3 & 15.0 & 60.0 & 54.5 & 84.7 & 88.5 & 85.9 & 84.5 & - \\
Labor markets & 3.2 & 24.2 & - & 34.7 & - & - & - & 60.0 & - \\
Finance & 1.0 & 3.6 & - & 6.3 & - & - & - & 9.0 & - \\
Real estate & 0.0 & - & 27.8 & 22.8 & 21.9 & 28.9 & 38.2 & 39.3 & - \\
Agriculture & 7.7 & 38.3 & 53.9 & 51.6 & 50.5 & 58.8 & 64.7 & 65.0 & - \\
Foreign trade & 1.5 & 3.0 & 19.0 & - & - & - & - & 41.4 & 54.4 \\
\hline
\end{tabular}

Source: Chen, $\mathrm{Wu}$, and Xie $(2000,14-25)$.

In the meanwhile, using five different methods, ${ }^{1}$ Chen, Wu, and Xie (2000) found that the overall marketization degree in China between 1979 and 1997 increased from basically zero to about 60 percent, as shown in figure 2 .

As China started its economic reform from the context of a highly centralized planned economy wherein the economy was tightly controlled by the government, the expansion of marketization in the Chinese economy was accompanied by the restructuring of the Chinese administrative state taking shape during the period of planned economy. Specifically, the marketization of the economy meant a fundamental alteration of the relationship between government and the economy, which required the overhaul of the administrative system in order to provide a set of institutions compatible with a market economy. Marketization, therefore, was the underlying dynamics of

1. The first method is the marketization of "weighted by composition of gross social products"; The second method is the marketization of "geometric weights of input factors prices"; The third method is the marketization "weighted by shares of three sectors"; The fourth method is the marketization of "GNP compositions synthetic weighting"; The fifth method is the "averaging market parameters", which just sum up the degree of marketization in different product and factor markets and then divided by the number of these product and factor markets, the average results is the overall degree of marketization in economy. For detailed information, please refer to Chen, $\mathrm{Wu}, \&$ Xie $(2000,29-37)$. 
Figure 2. Degree of Marketization in China Overall, 1979 to 1997

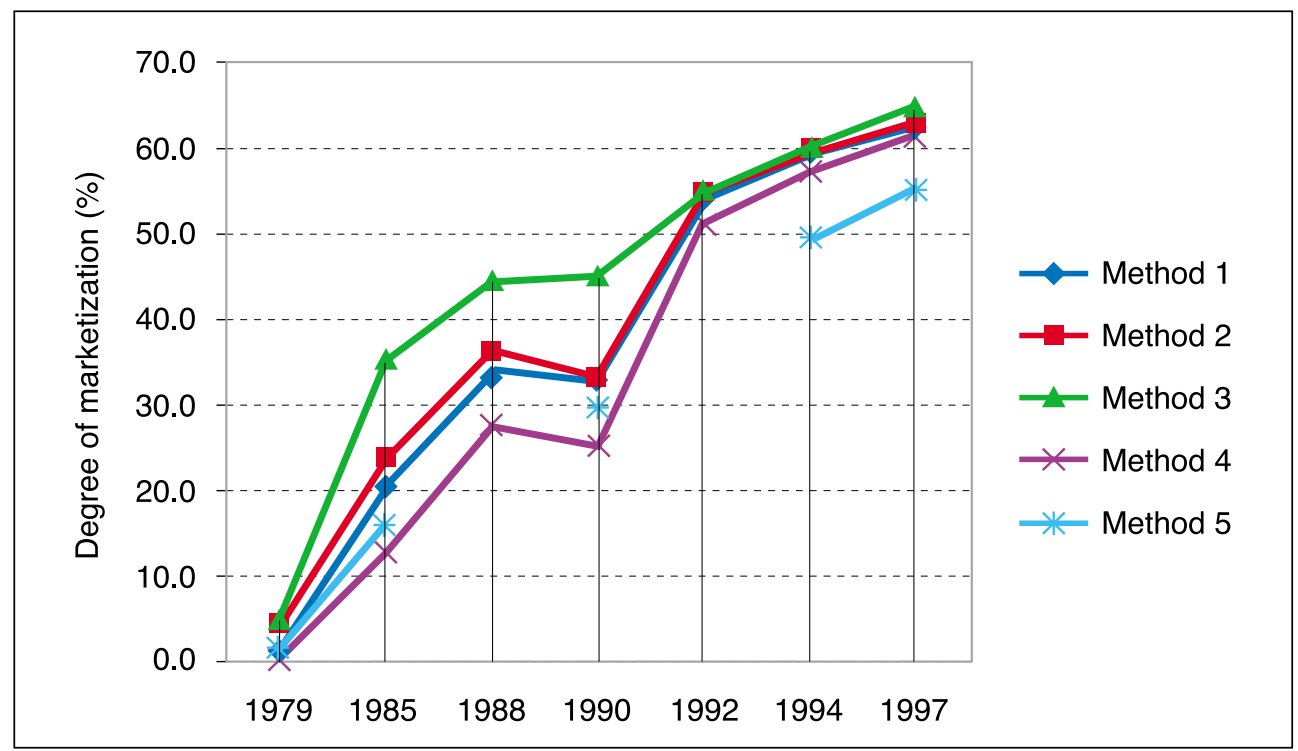

Source: Chen, Wu, \& Xie (2000, 38-39).

Chinese administrative reforms until the late 1990s. "While the Chinese state has played an important role in expanding the market, market expansion has, in turn, helped prepare the ground for the rationalization of the state" (Yang 2001, 19).

The Chinese administrative reforms throughout the 1980s and 1990s can be divided into two different phases. The first period was from 1982 to 1993, during which administrative reforms marked an initial step of remaking the administrative state for the purpose of transforming China from a centrally planned economy to a market economy. The second period was from 1998 onwards, featured with an ultimate goal to create a new administrative state to well serve the market economy (Zheng 2004a, 85). In the first phase, administrative reforms in China, e.g. the 1982 and 1988 administrative reforms, had been centered on downsizing, an unquestionable indicator that reformers during this period were yet unclear about the ultimate goal of China's economic reform and hence the proper role of the government in the economy. But, this had been fundamentally changed since the year of 1993 when the CCP announced the ultimate goal of China's economic reform was to develop a socialist market economy, which clearly and urgently demanded a new government for its emergence and operation. However, it was not until the year of 1998 that administrative reform as such was witnessed.

The Chinese government experienced dramatic growth immediately after the Cul- 
tural Revolution (1966-1976). The number of agencies in the State Council, for instance, grew from 52 in 1976 to 100 in 1981. In 1982, the CCP vowed in its 12th Congress to establish a mixed economy, with the planned economy as its main pillar and the market as its supplement. Obviously, the proliferation of old fashioned government agencies was unsuitable to the goal of developing markets within the planning system. Therefore, an ambitious restructuring of the State Council was implemented, with the number of agencies reduced from 100 to 61. More importantly, new agencies were created, either from scratch or by mergers, to enhance the market economy while reducing the role of the planning system (Zheng 2004a), as highlighted in table 2.

Table 2. Significant Aspects of the State Council Restructuring in 1982

\begin{tabular}{|c|c|c|}
\hline Agencies before restructuring & Agencies after restructuring & Restructuring objectives \\
\hline $\begin{array}{l}\text { State Economic Commission } \\
\text { State Agriculture Commission } \\
\text { State Infrastructure Construction Commission } \\
\text { State Industrial Machinery Commission } \\
\text { State Energy Commission } \\
\text { Finance and Trade Group } \\
\text { State Standards Bureau } \\
\text { State Measurement Bureau } \\
\text { State Bureau of Medicine Management } \\
\text { State Patent Office } \\
\text { State Bureau of Construction Material Industry }\end{array}$ & State Economic Commission & $\begin{array}{l}\text { Become a powerful } \\
\text { commission to promote the } \\
\text { market economy and to } \\
\text { counterbalance the State } \\
\text { Planning Commission. }\end{array}$ \\
\hline- & $\begin{array}{l}\text { State Commission for } \\
\text { Economic System Reform }\end{array}$ & $\begin{array}{l}\text { Guide and promote } \\
\text { marketization. }\end{array}$ \\
\hline $\begin{array}{l}\text { Ministry of Commerce } \\
\text { Ministry of Food } \\
\text { National Supply and Marketing Cooperative }\end{array}$ & Ministry of Commerce & $\begin{array}{l}\text { Enhance the development of } \\
\text { a domestic commodity market. }\end{array}$ \\
\hline
\end{tabular}

Source: compiled by the authors from Zheng (2004a, 87-88).

However, the 1982 administrative reform was limited in its effectiveness even in streamlining the Chinese bureaucracy. Five years later, in 1987, the number of State Council agencies rebounded to 72 . In 1987, the 13th CCP Congress granted market economy equal status with the planning economy. It called for building and nurturing a market system where the government should refrain from direct allocation of resources to enterprises and direct intervention in economy, the separation of party from government, a civil service, and strengthening the legal system. Although this indeed marked a major step to slim down the agencies at the core of the planned economy, the administrative reform carried out in 1988 resulted in only modest results. Both eco- 
nomic and administrative reforms were stalled between 1989 and 1992 because of the June 4 Incident of the year of 1989 when (Yang 2001; 2004, 25-37). As a matter of fact, the Chinese administrative reforms throughout the 1980s and early 1990s achieved few results, and were trapped in a cycle of "streamlining-bloating-more streamlining-more bloating" (Ngok \& Zhu 2007; Yang 2001). The failure was partly because of the resistance from the old system, but fundamentally, it was because that during this period the ultimate goal of China's economic reform had not been decisively set up, and consequently, the goal of administrative reforms remained vague. As Yang (2001) pointed out, as long as the economic reform has not reached the point that the government has been disconnected from the economy and the market has gained its autonomy, this is inevitable.

After Deng Xiaoping's Southern Tour in 1992, the market-oriented economic reform regained momentum and accelerated. In the 14th CCP Congress of 1993, the market economy was officially legitimated and enshrined as the ultimate goal of economic reform. A new wave of administrative reforms was launched in 1993. Most importantly, with the goal of economic reform having been clearly defined, the direction of administrative reforms was clearly delineated as well. As Yang (2001) pointed out, the progress of the marketization movement eventually led to a consensus among the Chinese leadership that the success of economic reform required a fundamental restructuring of the administrative system in line with the logic of the market economy. Consequently, unlike the previous reforms, the 1993 administrative reform focused on the transformation of governmental functions to better cater to the demands of the market economy. It emphasized the separation of government from SOEs. It made efforts to rationalize and professionalize the civil service system through the country's first law of civil service. However, the 1993 reform has not achieved most of its goals at the central level. Although ministries and functionaries of the State Council was reduced from 86 to 59 and the personnel of the central government was cut by $20 \%$, a large amount of economic ministries and functionaries with a direct intervention in economy remains intact (Ngok \& Zhu 2007). In general, from 1992 to 1997, reforms in the central government proceeded slowly without much progress, although there were many experiments with government rationalization at the local level (Yang 2001). This suggested that before the market economy developed to certain degree of maturity, administrative reform couldn't make much progress.

However incremental the economic reform was, by the late 1990s the cumulative effects of marketization had successfully nurtured a burgeoning market economy. In order to create a government well suited to the requirement of market economy, the leadership in the 15th CCP Congress of 1997 called for a new round of administrative reform, with transformation of governmental functions as the top priority. In March 
1998, the newly elected premier, Zhu Rongji, introduced a sweeping restructuring of the State Council, reducing the number of commissions and ministries from 40 to 29. The size of the civil service was trimmed by nearly half (Yang 2001; Zheng 2004a). Most importantly, the 1998 reform finally transformed a Chinese government designed for central planning and bureaucratic command to a new administrative state with institutions compatible to the operation of a modern market economy (Lan 1999; Yang 2001; 2004). Most of industrial ministries, which were the backbones of the planned economy, were consolidated into a MITI-style State Economic and Trade Commission. Table 3 highlights some of the most significant restructurings in the 1998 reform.

Table 3. Significant Aspects of the State Council Restructuring in 1998

\begin{tabular}{|c|c|c|}
\hline Agencies before restructuring & Agencies after restructuring & Restructuring objectives \\
\hline State Economic and Trade Commission & \multirow{10}{*}{$\begin{array}{l}\text { State Economic and Trade } \\
\text { Commission }\end{array}$} & \multirow{10}{*}{$\begin{array}{l}\text { Oversee and regulate } \\
\text { industrial enterprises in the } \\
\text { market economy. }\end{array}$} \\
\hline Ministry of Power & & \\
\hline Ministry of Coal Industry & & \\
\hline Ministry of Metallurgical Industry & & \\
\hline Ministry of Chemical Industry & & \\
\hline Ministry of Internal Trade & & \\
\hline Textile Industry Council & & \\
\hline Light Industry Council & & \\
\hline General Company of Petroleum and Gas & & \\
\hline General Company of Chemical Industry & & \\
\hline State Planning Commission & $\begin{array}{l}\text { State Development and } \\
\text { Planning Commission }\end{array}$ & $\begin{array}{l}\text { Shift its main focus from } \\
\text { planning to maintaining a } \\
\text { medium- and long-term overall } \\
\text { balance in economic } \\
\text { development. }\end{array}$ \\
\hline Ministry of Labor & \multirow{3}{*}{$\begin{array}{l}\text { Ministry of Labor and Social } \\
\text { Security }\end{array}$} & \multirow{3}{*}{$\begin{array}{l}\text { Provide the institutions } \\
\text { necessary for a market } \\
\text { economy. }\end{array}$} \\
\hline $\begin{array}{l}\text { Social Security Department of the Ministry of } \\
\text { Personnel }\end{array}$ & & \\
\hline $\begin{array}{l}\text { Insurance Department of the Ministry of } \\
\text { Public Health }\end{array}$ & & \\
\hline $\begin{array}{l}\text { State Commission for Economic Systems } \\
\text { Reform }\end{array}$ & - & $\begin{array}{l}\text { Market-oriented reform had } \\
\text { been basically accomplished, } \\
\text { so this agency was abolished. }\end{array}$ \\
\hline Ministry of Electrical Industry & \multirow{3}{*}{$\begin{array}{l}\text { Ministry of Information } \\
\text { Industry }\end{array}$} & \multirow{3}{*}{$\begin{array}{l}\text { Oversee key industrial sectors } \\
\text { in China's information } \\
\text { revolution. }\end{array}$} \\
\hline Ministry of Post and Communication & & \\
\hline Ministry of Radio, Film, and Television & & \\
\hline
\end{tabular}

Source: compiled by the authors from Luo (1998). 
Figure 3 shows the impact of the first four rounds of administrative reforms in 1980s and 1990s. The two most radical changes took place in 1982 and 1998. In the 1982 reform, the total number of commissions and ministries was cut by 17 percent. Those directly involved in supervising the micro-operation of economy was reduced even more by 20 percent. In the 1998 reform, the size of total commission and ministries declined by 27.5 percent, while those in economic sphere was chopped by 50 percent.

Figure 3. Organizational Changes to the State Council in 1982, 1988, 1993, and 1998

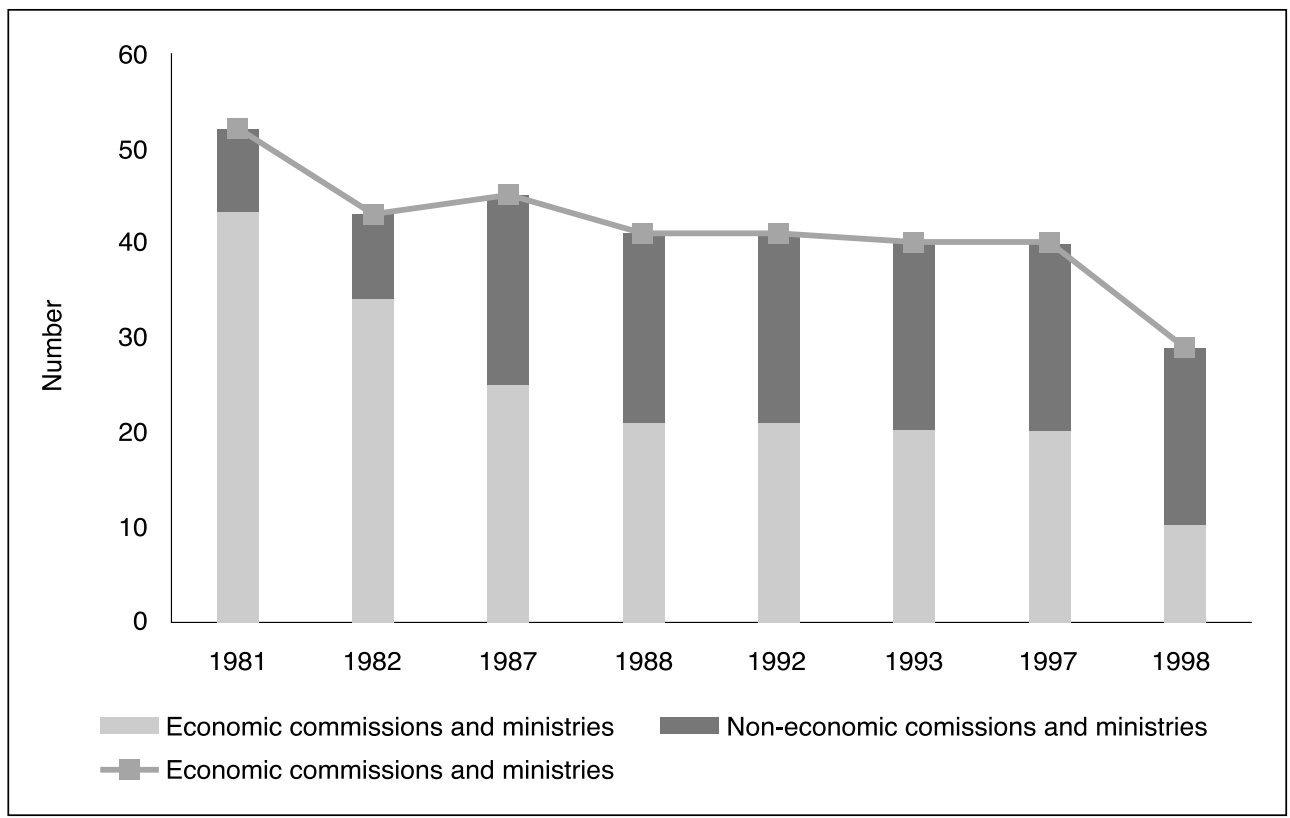

Source: compiled by the authors from Zheng (2004a, 83-108).

Following the far-reaching 1998 administrative reform, the Chinese government launched a series of new measures to further withdraw government from direct intervention in the market, especially to limit the administrative discretion over market operations. After the four rounds of administrative reforms in 1982, 1988, 1993, and 1998, the role of planning in the economy had dramatically shrunk. However, the administrative permits system, the fundamental bulwark of the planned economy, remained unbroken and even proliferated, largely due to the self-interest of rent-seeking bureaucrats (Yang 2004, 152-3). This resulted in increased burdens on business, organizational corruption, and the erosion of the legitimacy of the Chinese administrative state (Lu 2000; Yang 2004, 152-3), conflicting with the further advancement of marketization.

Of course, the 1998 reform had already contributed to a significant reduction of 
administrative permits. Particularly at the local level, governments competing for business investments cut the administrative permits considerably. By 2001, it was reported that local authorities had canceled or delegated 30-60 percent of pre-existing administrative permit requirements. The reform gained momentum after China's entry into the World Trade Organization (WTO). In compliance with WTO's terms, the State Council cancelled 789 permit items in 2002 and 406 in 2003. In 2004, China passed the Administrative Permits Law, establishing a new system in which only those socioeconomic activities associated with national security, public safety, macroeconomic control, ecological and environmental protection, and personal health and safety required administrative permits. This fundamentally limited the scope of administrative power over businesses and individuals and enabled the market system to play a more and more important role in economic affairs (Yang 2004, 154-64). Other reforms were carried out as well, such as the establishment of one-stop administrative service centers. Undoubtedly, all these reforms mostly benefited the business sector, an indicator that Chinese governments, especially local governments, were becoming much more probusiness. In sum, marketization was reshaping the Chinese administrative state.

\section{ADMINISTRATIVE REFORMS RECENTLY: ANOTHER SIDE OF THE STORY}

The Chinese economic reform has generated great achievements. China has been so far successful in its dual transformations: from a centrally planned economy to a market economy and from a backward and poor country to an economic power. The China miracle, however, was accomplished with tremendous social and environmental costs.

By the mid-1990s, it was increasingly clear that, contrary to the neoliberal belief that the benefits of economic growth would trickle down to all levels of society, economic growth in China had created severe income inequality. In the initial stages of economic reform until 1985, farmers were the major beneficiaries, and the urban-rural income gap narrowed significantly. Measured by the Gini coefficient, it dropped from 0.32 in 1980 to 0.26 in 1984 (Chen, Hou, \& Jin 2008; Luo \& Zhu 2008; Riskin 1997). However, as marketization accelerated and expanded to the cities in the mid-1980s, China saw an increasing rise of income inequality. In 2003, the Gini coefficient jumped to 0.45 , indicating a higher level of income inequality. At the beginning of twenty-first century, a large portion of China's wealth is concentrated in the top 20 percent of the population (Gries \& Rosen 2004; World Bank 2005).

As shown in figure 4, starting with the mid-1980s, the Gini coefficient has generally been increasing, from 0.26 in 1985 to 0.44 in 2005 . The widening income gap during 
this period can be largely attributed to the increase in urban-rural income disparity. The Gini curve basically overlaps with the urban-to-rural income ratio; the ratio of urban to rural per capita nominal income was 2.57 in 1978, dropped to 1.86 in 1985 , and soared to 3.22 in 2005. In addition, since the mid-1990s, city dwellers have also experienced income disparity among themselves. The intra-urban Gini coefficient increased, for instance, from 0.28 in 1995 to 0.319 in 2002 (Li \& Yue 2007).

Figure 4. Income Inequality in China, 1978-2005

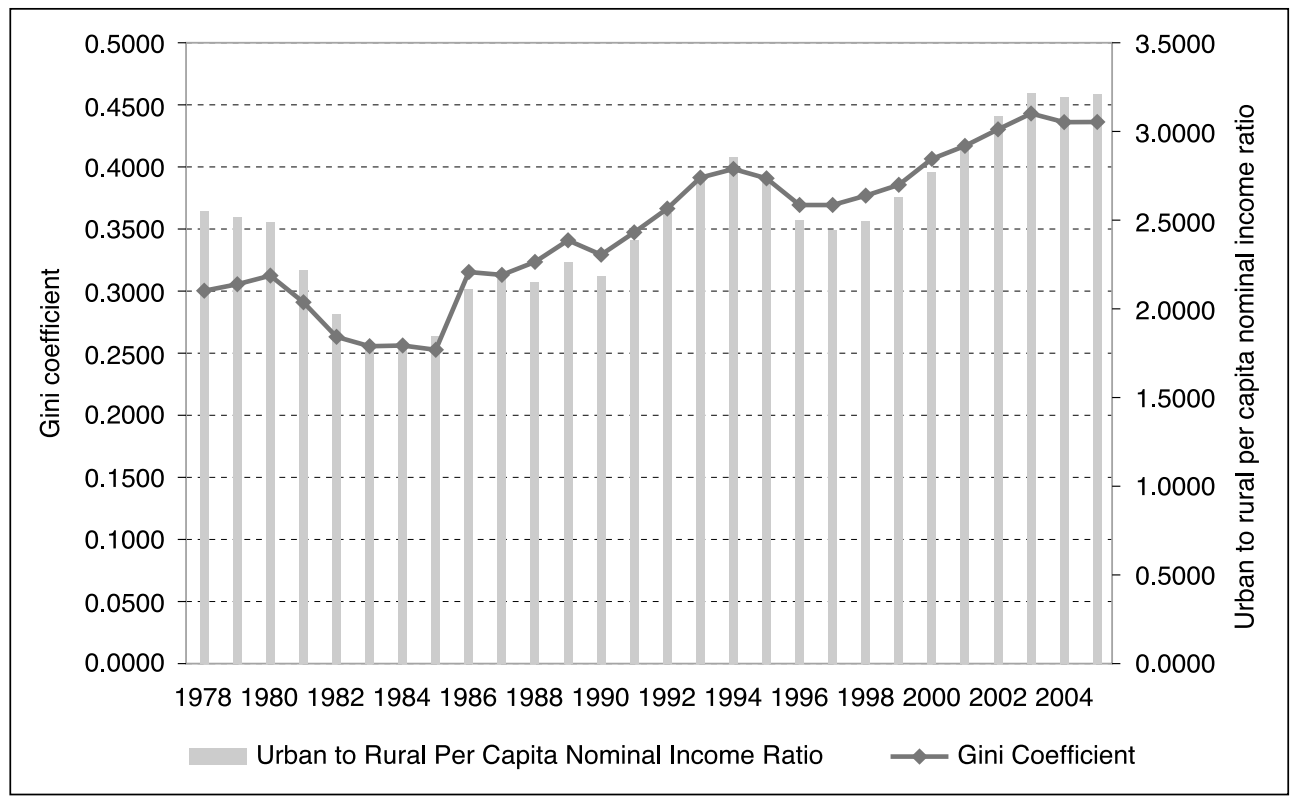

Source: Chen, Hou, \& Jin (2008), Luo \& Zhu (2008).

The rise of income inequality can be ascribed to multiple causes, such as the inappropriate state monopoly, biased government policies that led to the segregation of urban and rural labor markets, the social welfare provided mainly to urban residents, such as pensions, health care, and education, and heavy tax or fee burdens on rural citizens (Chen 2007; Li \& Yue 2007). Equally important, however, was the inactiveness of the government in providing social protection for citizens; relying mainly on the market system as the basic mechanism of income distribution also contributed to the widening income inequity. With the disintegration of the socialist welfare system, the Chinese government was sluggish in creating a new system to replace it. Consequently, millions of poor people were in fact thrown into the market-driven economy without protection from the government. There had been a great lag between economic devel- 
opment and social development or social policy (Chan, Ngok, \& Phillips 2008, xiii; Wang 2007). ${ }^{2}$ The 1998 administrative reform attempted to keep pace with marketization. Its achievements, however, were limited in face of these negative social consequences of the development of market economy.

The market, in history, evolved along with the development of state regulation (Polanyi [1944] 1957). In the process of marketization, China developed a market regulation system either by creating new regulatory agencies or by granting market supervisory authority to existing agencies. However, the obsession of the Chinese government, particularly at the local level, with economic growth undermined the effectiveness of the regulatory framework. The unfettered market led to environmental degradation and increasing food and drug safety problems.

According to Pei $(2006,175)$, even official reports admit that a third of China's land suffers from severe soil erosion. Erosion and the resulting silt have endangered China's land reservoirs. Each year, about 2,500 square kilometers of land are converted into desert. Moreover, each year, 440 million tons of wastewater is released, which is 80 percent beyond the ecological capacity. Of that, 80 percent is discharged untreated, and three quarters of the lakes and about half of the rivers have been polluted. Two thirds of underground water in the 118 major cities is severely polluted. In addition, more than 20 million tons of SO2 is released into the air each year. Of the cities with the worst air pollution in the world in 1999, seven were located in China (Chang 1998, 116-17; Ho 2006). The ineffectiveness of governmental regulation in protecting the environment in China stems mainly from the unwillingness of government, especially at the local level, to enforce it. Pushed by the strong urge for economic growth, local governments tended to regard environmental protection as an extra burden. Moreover, many government officials held the belief that environmental problems would be resolved once China has become prosperous (Brettell, 2007), which well illustrates itself in so-called "pollute first, clean up later" (Ho 2006).

The excessive marketization also led to an unfettered market, which has become to be a market increasingly beset with food and drug safety problems. Since the 1990s, Chinese markets had begun to be flooded with unsafe foods and drugs, often resulting in deaths or injuries. In September 2008, for instance, immediately after the spectacular

2. There is a large and fast-growing body of literature that documents the social sufferings arising from the expansion of market system and the irresponsiveness of the government in providing social protection. For example, Solinger (2001) analyzed the emergence of a new underclass in the urban areas, including laid-off workers from SOEs with merge social security, rural migrants, and the urban poor. Wright's study (2004) exposed the extremely bad working conditions for many rural migrants in coal mining. Despite many regulations on mine safety, powerful market forces work to keep many unsafe small mines in business. 
Beijing Olympic Games, a scandal regarding infant milk powder brought China's food safety problems to global attention again. The milk power was contaminated with toxic melamine, which made it appear to have more protein, causing at least three deaths of infants. Later on, the scope of scandal was widened, and most of the entire dairy industry was found to have products tainted by melamine (Chao \& Leow 2008). Undoubtedly, greedy businessmen must be charged for the proliferation of unsafe foods and drugs, but local governments, who are totally occupied by economic growth and fiscal revenue maximization and thus reluctant to rein in the business activities, cannot escape from being blamed (Tam \& Yang 2007).

In face of these mounting social problems, a responsible government is needed. However, despite more than two decades of anticorruption efforts, China continues to be riddled with corruption. For instance, the reluctance of localities to enforce regulations over food and drug safety was rooted in corruption, which can explain part of the widespread proliferation of unsafe foods and drugs. Indeed, with the political power structure unchanged in the reform era, the marketization and commercialization of the economy not only provided more resources to be corrupted but in many cases was accompanied with the development of collusion between businessmen and officials. Consequently, corruption became pervasive, institutionalized, collectivized, and increasingly intensified during the marketization process (Chen 2002; Fan \& Grosssman 2001; Gong 2002, 2006; Hao 1999; Larsson 2006; Meagher 2005; Shieh 2005; Sun 2005; Wedeman 2004). According to Hu Angang (2007, 217-33), the economic costs of corruption in China amounted to 14.5 to 14.9 percent of GDP each year between 1999 and 2001.

To sum up, the unfettered market forces unleashed by the marketization movement, which was accompanied with the government's withdrawal from providing social protection and the ineffectiveness of governmental regulation over market, has led to mounting social consequences in China. In Polanyi's words, the "market economy if left to evolve according to its own laws would create great and permanent evils" ([1944] 1957, 136). While marketization seemed to reach its zenith in China by the late 1990s, simultaneously a countermovement of self-protection of society was afoot, embodied in the rapid growth of popular unrest and other collective actions, the rise of civil society (particularly independent NGOs), and the emergence of a Chinese version of muckraking, all demanding and eventually leading to institutional changes in the government.

\section{Popular Unrest}

Market-oriented economic reforms resulted in and intensified social discontents, largely due to the increase of income disparity, the government's withdrawal from pro- 
viding social protection, and the proliferation of corruption, among three main groups: workers, farmers, and home- and landowners. Consequently, popular unrest has become virtually a norm in China since the mid-1990s (Perry \& Selden 2000; Zheng 2004b, 148 and 293). Workers protested against unprotected layoffs, official corruption, Dickensian working conditions, and the state's inactiveness in alleviating their pains (Chang 1998, 112-13; Solinger 2004; Weston 2004). Peasants were growing restive in the late 1990s when they found it increasingly difficult to survive in face of diminishing income growth and increasing demands for funds from exploitive local governments (Chang 1998, 110-12). Homeowners and landowners protested against illegal evictions and inadequate compensations (Cai 2007). ${ }^{3}$ As shown in figure 5, popular protests have increased tenfold - from 8,700 in 1993 to 87,000 in 2005-and continue to expand in scale.

Figure 5. Popular Protests in China, 1993-2005

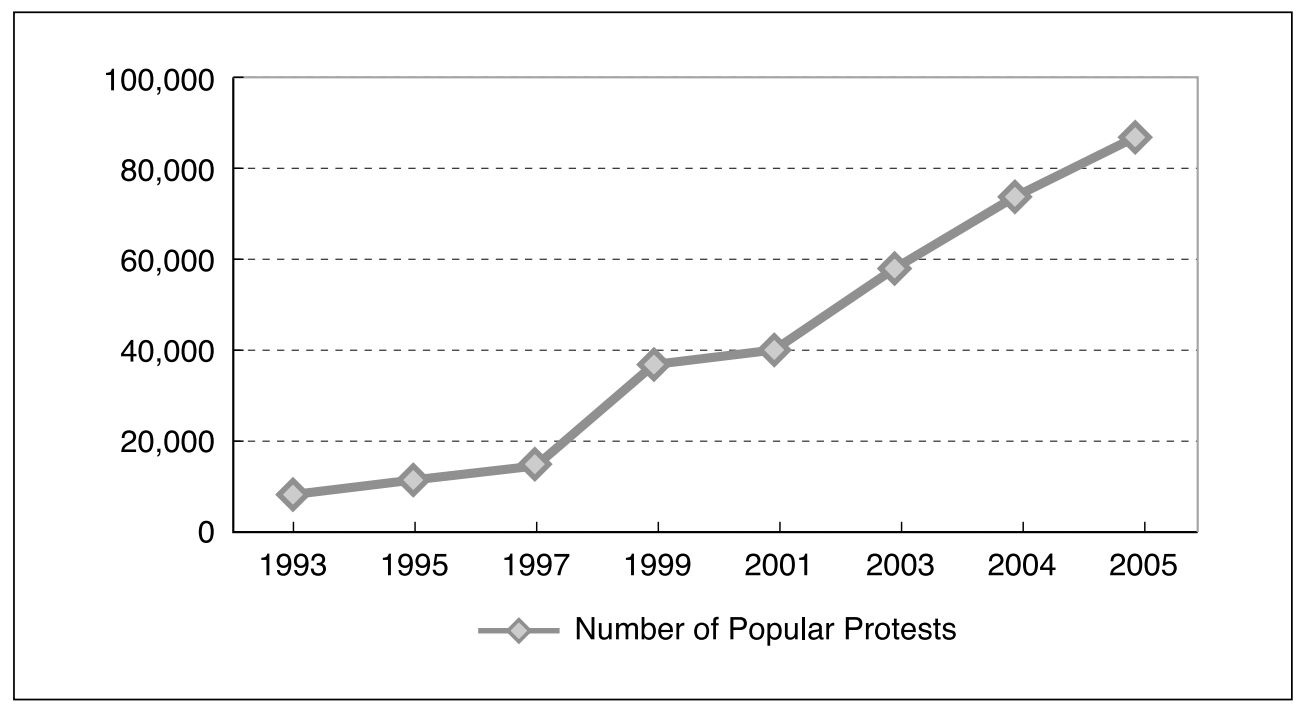

Source: Qiao \& Jiang (2005) and Yu (2007).

3. Recent protests involving farmers, workers, and homeowners (Lum, 2006) include the following: In January 2006, thousands of protesters clashed with police over inadequate compensation for farmland taken for industrial use in Panlong village, Sanjiao township, Guangdong province. In September 2005, over 100 workers at a shoe factory in Guangzhou battled police and smashed vehicles over unpaid wages. In November 2008, 9,000 cab drivers in Chongqing went on strike to protest the way fares were divided between drivers and companies. In August 2005, 100 people demonstrated outside a meeting of Shanghai's legislature, protesting housing disputes and land seizures around the city. 


\section{The Rise of Independent NGOs}

The economic transition also contributed to a restructuring of the social fabric, greater social differentiation and mobility, further withdrawal of state influence in the public sphere, and the resulting expansion of autonomous realms of society. In this context, a nascent civil society, with new social associations and non-governmental organizations (NGOs) with varying degrees of autonomy, has burgeoned in China since the early 1990s to address a wide range of social needs, grievances, and interests (Howell \& Pearce 2001, 124; Ma 2006).

Underlying the growing social unrest and the rise of civil society was the awaking consciousness of citizen rights in China. In the 1990s, the society as a whole had been awaked to address these rights and protect them from the penetration of market forces as well as the intrusion of the state which is increasingly pro-business (Goldman 2005).

In fact, the activities of these NGOs can be roughly classified into two categories: defending social rights and delivering social services. The fast growth of NGOs in China, therefore, was indicative of the rapid rise of the movement for self-protection of society. Particularly, those NGOs involved in environmental protection, AIDS prevention, and issues relating to social and economic justice started to more actively engage in a new form of advocacy, aimed at influencing policy as well as promoting public participation for the self-protection of society (Mol 2006; Morton 2005; Wang 2006).

\section{Muckraking, Chinese Style}

The Chinese mass media still remained under tight control by the CCP. Many media entities, however, driven by social conscience and justice as well as economic incentives to compete for viewers and readers, dared to challenge the "propaganda state" and disclose the dark side of excessive penetration by the market. The development of the Internet further enhanced this momentum (Wang 2007). With a rising consciousness of citizen rights, the Internet has become the most direct tool for accountability politics in China. Similar to American muckraking or investigative journalism during the Progressive Era, the Chinese version played a critical role in the self-protection of society movement.

The self-protection of society movement produced repeated calls for institutional responses from the Chinese administrative state (Lewis \& Xue 2003). In response to the growing pressures and demands from society, the Chinese government refocused its efforts and reset its agenda in state rebuilding, typically reflected in the 2003 and 2008 administrative reforms. While administrative reforms in the 1980s and 1990s 
were to build up an administrative state compatible with the development of a market economy, the reforms of 2003 and 2008 revealed different characteristics.

The 2003 administrative reform marked a turning point. Marketization was still an important driving force for administrative reform, because a complete market system was still coming in shape. Particularly, marketization has not been evenly carried out in all sectors. While market system has played dominant role in agricultural and industrial sectors and some service sectors, a few sectors remains monopolized in various degrees by state ownership or by state regulation, particularly banking and insurance, railway, telecommunication, etc. Also, commodity markets are more open than factor markets; in the latter, the use of labor is most marketized, but financial and capital markets are less competitive (Wang 2004). Meanwhile, the Chinese administrative state invested more efforts in responding to social issues arising from the development of market economy. According to then Secretary-General of the State Council Wang Zhongyu, the basic content of administrative reform in 2003 was to deepen the reform of the state asset management system, the macroeconomic management system, the financial supervisory framework, and the trade management system, and, for the first time, to strengthen the food and work safety supervisory system (Wang 2003). Obviously, administrative reform now has begun to be driven by the double movements as shown in table 4.

Table 4. Significant Aspects of the State Council Restructuring in 2003

\begin{tabular}{l|l|l}
\hline \multicolumn{1}{c|}{$\begin{array}{c}\text { Agencies before } \\
\text { restructuring }\end{array}$} & \multicolumn{1}{|c}{ Agencies after restructuring } & \multicolumn{1}{c}{ Driving forces and policy objectives } \\
\hline- & $\begin{array}{l}\text { State-Owned Asset Supervision and } \\
\text { Administration Commission }\end{array}$ & $\begin{array}{l}\text { Marketization } \\
\text { Objectives: to manage state assets } \\
\text { and to supervise the performance of } \\
\text { central-government-owned enterprises. } \\
\text { Its responsibilities in value retaining } \\
\text { and increment of state assets were } \\
\text { emphasized after many years of state } \\
\text { asset-stripping. }\end{array}$ \\
\hline $\begin{array}{l}\text { State Development } \\
\text { and Planning }\end{array}$ & $\begin{array}{l}\text { State Development and Reform } \\
\text { Commission }\end{array}$ & $\begin{array}{l}\text { Marketization and self-protection } \\
\text { of society } \\
\text { Objectives: to establish a primary } \\
\text { macroeconomic management agency } \\
\text { while completely withdrawing from } \\
\text { micromanagement of enterprises; to } \\
\text { formulate social development policies. }\end{array}$ \\
\hline- & $\begin{array}{l}\text { Marketization } \\
\text { Objective: to regulate and supervise } \\
\text { the banking system in China, which } \\
\text { was about to be totally liberalized. }\end{array}$ \\
\hline
\end{tabular}




\begin{tabular}{l|l|l}
\hline \multicolumn{1}{c}{$\begin{array}{c}\text { Agencies before } \\
\text { restructuring }\end{array}$} & \multicolumn{1}{|c}{ Agencies after restructuring } & \multicolumn{1}{c}{ Driving forces and policy objectives } \\
\hline- & Ministry of Commerce & $\begin{array}{l}\text { Marketization } \\
\text { Objective: to enhance and perfect the } \\
\text { market system through rule and } \\
\text { institution-building, supervision of } \\
\text { market operations, and international } \\
\text { economic cooperation. }\end{array}$ \\
\hline- & $\begin{array}{l}\text { State Food and Drug Administration } \\
\text { (directly under State Council) }\end{array}$ & $\begin{array}{l}\text { Self-protection of society } \\
\text { Objective: to strengthen food and } \\
\text { drug safety. }\end{array}$ \\
\hline- & $\begin{array}{l}\text { State Administration of Work Safety } \\
\text { (directly under State Council) }\end{array}$ & $\begin{array}{l}\text { Self-protection of society } \\
\text { Objective: to supervise work safety, } \\
\text { particularly in the coal mining industry. }\end{array}$ \\
\hline $\begin{array}{l}\text { State Administration } \\
\text { of Environmental }\end{array}$ & $\begin{array}{l}\text { State General Administration of } \\
\text { Environmental Protection }\end{array}$ & $\begin{array}{l}\text { Self-protection of society } \\
\text { Objectives: to upgrade the agency to } \\
\text { ministerial status and give it more } \\
\text { enforcement resources and authority } \\
\text { in order to strengthen environmental } \\
\text { protection. }\end{array}$ \\
\hline
\end{tabular}

Source: compiled by the authors from Wang (2003).

Apparently, both forces, marketization and self-protection of society, shaped the administrative reform of 2003. Marketization continues to influence the restructuring of Chinese administrative state; more institutions compatible with market economy were created. The previous planning ministry was reshuffled to be a key macroeconomic management agency. The Ministry of Commerce was established to facilitate market development and operation. The Banking Regulatory Commission was created to ensure stability of the financial system. In the meantime, new institutions aimed at protecting society from the excessive penetration of market were also founded. Some institutions that had previously had a purely economic function, such as the State Development and Reform Commission, were re-endowed with more functions in the societal sphere. After more than two decades' rapid marketization, the society was rediscovered in China's state rebuilding. In this sense, the 2003 reform did represent a significant departure from previous reforms preoccupied with the single aim of developing a modern market economy. Furthermore, it was clear that the 2003 administrative reform was with a new intension to achieve a balance between marketization and the self-protection of society.

Indeed, the year 2003 also marked a fundamental shift in the direction of China's development strategy. In the Third Plenum of the CCP's 16th Party Congress held in October 2003, the CCP leadership vowed that all policy-making must be under the 
guidance of "the scientific development concept," which emphasized sustainable development, social welfare, a human-centered society, increased democracy, and a harmonious society. This undoubtedly proposed a new development strategy totally different from the old mode centered on economic development. In 2006, corresponding to this general trend, the Sixth Plenum of the CCP's 16th Party Congress chose a fundamentally different route toward China's future by proclaiming that the chief mission of the CCP and hence the government was to establish a "harmonious society" by 2020. The 2007 Party Congress further enshrined the "scientific development concept" in the party's constitution (Leonard 2008, 48-9; Wang 2007).

The harmonious society articulated by the CCP's 2006 Plenum is clearly a response of the Chinese state to the demands associated with the movement for the self-protection of society. It contains five eleme: 1) a democratic society under the rule of law; 2) a society based on equality and justice; 3) an honest and caring society; 4) a stable, vigorous, and orderly society; and 5) a society in which humans lived in harmony with nature. As Woo (2007) stated, "the obvious implication from this new party line was that the present major social, economic, and political trends within China might not lead to a harmonious society with the preceding characteristics." With the change of development strategy, the reform route that has long been guided by marketization was comprehensively reexamined, and the direction toward China's future was reoriented. The new emphasis on harmonious society and scientific development stood for "a range of new policies intended to restore a balance between the country's thriving market economy and its neglected socialist past" (Leonard 2008, 48).

In line with this new development strategy, a new wave of administrative reform was initiated in 2008. While the endeavor to complete market-oriented reforms was still a high priority, for the first time social development became as significant as economic development in defining administrative reforms. Both marketization and the self-protection of society witnessed their influences in the 2008 administrative reform. According to then Secretary-General of the State Council Hua Jianmin (2008), the ultimate goals of the 2008 reform were 1) to further withdraw excessive governmental involvement from microeconomic activities; 2) to strengthen the government's capacity to promote social development and provide public service; and 3) to enhance the checks and balances among three powers within the government: decision-making, implementation, and supervision. Specifically, the 2008 reform proposed eight major measures corresponding to eight specific objectives. As table 5 shows, four measures were motivated by marketization, while the other four were driven by the concerns of protecting the benefit of society.

Three fundamental characteristics of the 2008 administrative reform deserve highlighting. First, the reform measures motivated by marketization were intended to 
Table 5. Significant Aspects of the State Council Restructuring in 2008

\begin{tabular}{|c|c|c|}
\hline Policy objectives & Reform measures & Main driving forces \\
\hline $\begin{array}{l}\text { Coordinate the functions of } \\
\text { macroeconomic management } \\
\text { ministries and to establish an } \\
\text { efficient macroeconomic } \\
\text { regulatory system. }\end{array}$ & $\begin{array}{l}\text { Enhance coordination among the } \\
\text { State Development and Reform } \\
\text { Commission, the Ministry of } \\
\text { Finance, and the People's Bank } \\
\text { (the central bank). }\end{array}$ & $\begin{array}{l}\text { Marketization } \\
\text { The market economy requires that economic } \\
\text { agencies work together to maintain an overall } \\
\text { economic balance, curb inflation and recession, } \\
\text { and optimize economic structure. }\end{array}$ \\
\hline $\begin{array}{l}\text { Strengthen the energy } \\
\text { management agencies. }\end{array}$ & $\begin{array}{l}\text { Establish the State } \\
\text { Administration of Energy. }\end{array}$ & $\begin{array}{l}\text { Marketization } \\
\text { The market economy calls for stabilizing and } \\
\text { securing energy by regulating the energy } \\
\text { industry and promoting new forms of energy. }\end{array}$ \\
\hline $\begin{array}{l}\text { Accelerate a new mode of } \\
\text { industrialization. }\end{array}$ & $\begin{array}{l}\text { Create the Ministry of Industry } \\
\text { and Information Technology. }\end{array}$ & $\begin{array}{l}\text { Marketization } \\
\text { The market economy demands effective } \\
\text { government regulation of industrial enterprises } \\
\text { via industrial policies, sectoral standards, } \\
\text { and technological innovations. }\end{array}$ \\
\hline $\begin{array}{l}\text { Develop a comprehensive } \\
\text { network of transportation. }\end{array}$ & $\begin{array}{l}\text { Reorganize the Ministry of } \\
\text { Transport to consolidate land and } \\
\text { water transportation with aviation. }\end{array}$ & $\begin{array}{l}\text { Marketization } \\
\text { The market economy requires an efficient } \\
\text { transportation network as the precondition of } \\
\text { economic development. }\end{array}$ \\
\hline $\begin{array}{l}\text { Improve the employment and } \\
\text { social security system. }\end{array}$ & $\begin{array}{l}\text { Establish the Ministry of Human } \\
\text { Resources and Social Security. }\end{array}$ & $\begin{array}{l}\text { Social protection } \\
\text { The self-protection of society requires effective } \\
\text { labor supervision, an accessible employment } \\
\text { service system, equal income distribution, and } \\
\text { an efficient social security framework. }\end{array}$ \\
\hline $\begin{array}{l}\text { Strengthen the enforcement } \\
\text { of environmental protection. }\end{array}$ & $\begin{array}{l}\text { Establish the Ministry of } \\
\text { Environmental Protection. }\end{array}$ & $\begin{array}{l}\text { Social protection } \\
\text { The self-protection of society requires that the } \\
\text { environment be used sustainably and protected } \\
\text { from unfettered market forces. }\end{array}$ \\
\hline $\begin{array}{l}\text { Construct a public housing } \\
\text { system and coordinate urban } \\
\text { and rural development. }\end{array}$ & $\begin{array}{l}\text { Set up the Ministry of Housing } \\
\text { and Urban-Rural Development. }\end{array}$ & $\begin{array}{l}\text { Social protection } \\
\text { The self-protection of society requires effective } \\
\text { provision of basic living conditions for both } \\
\text { urban and rural residents. }\end{array}$ \\
\hline $\begin{array}{l}\text { Fine-tune the Food and Drug } \\
\text { Safety Supervisory System. }\end{array}$ & $\begin{array}{l}\text { Move the State Administration of } \\
\text { Food and Drug Safety under the } \\
\text { supervision of the Ministry of } \\
\text { Public Health. }\end{array}$ & $\begin{array}{l}\text { Social protection } \\
\text { The self-protection of society requires } \\
\text { enhanced regulation of food and drugs to } \\
\text { safeguard human life and health. }\end{array}$ \\
\hline
\end{tabular}

Source: compiled by the authors from Hua (2008).

improve the effectiveness of the economic regulatory regime's macroeconomic management system, with a emphasis on sustainable, rapid, and sound development of the economy. In Hua's words (2008), these measures were meant to advance "scientific development" rather than the previous mode of economic development which was 
achieved at the cost of environmental deterioration and higher resource consumption. Second, the reform measures paid significant attention to social security and the improvement of people's well-being. The administrative restructuring was no long solely oriented to strengthening the market economy, but was reoriented to be more concerned of social management and service. Third, super-ministries were proposed to consolidate and integrate organizational structures and functions to cope with complex social and economic issues associated with the current socioeconomic transition.

It is evident that, therefore, protecting the benefit of society exercised significant influence on the 2008 administrative reform. However, not all of these measures have been in effect. For example, the establishment of super-ministries has far from been finished and is faced with many resistances from governmental bureaucracies.

\section{CONCLUSION AND DISCUSSION}

The underlying dynamics of Chinese administrative reforms since 1978 have been interpreted either as a Chinese version of NPM or solely as a rationalization process to reconfigure the administrative state to be more compatible with the operation of the market economy.

Both conceptualizations are limited. The former fails to grasp the unique essence of China's administrative reform. Though some China's reform measures, such as privatization of SOEs, appeared similar to NPM, the fundamental nature of China's administrative reform is not a variation of NPM. While NPM is more emphasized on adopting market mechanism in the operation of the government, the focus of Chinese administrative reforms was on marketizing of China's economy. With regard to the latter view, it at best provides an incomplete picture of the inherent logic of rebuilding the Chinese administrative state during the reform era.

Borrowing from Polanyi's concept of a double movement, this paper has argued that the marketization movement is just one of the dynamics that has driven Chinese administrative reforms; the other is the self-protection of society.

The initial years of the Chinese administrative reforms were indeed a singledimensioned restructuring process catering to the demands of developing a modern market economy, which was believed by the leadership and by most Chinese people to be capable of bringing China toward prosperity. Guided by market liberalism, the administrative reforms of 1982, 1988, 1993, and 1998 altered the relationship between the state and the economy. They greatly boosted the advancement of the market, which contributed to the Chinese economic miracle and fundamentally changed the landscape of the Chinese economy. In the meanwhile, however, once the market was 
institutionalized and able to develop according to its own laws, it resulted in mounting social costs. A countermovement, the self-protection of society, emerged vigorously as marketization reached its apex in the late 1990s. It asked for an institutional response from the government to address social grievances and protect society from the excessive penetration of market.

Since then, confronting the demands from two opposite directions, Chinese administrative reforms have progressed in the context of this tension between the double movements. Starting in the late 1990s, the double movements, marketization and the self-protection of society, concurrently directed and defined the agenda of China's administrative reform. Marketization continues to influence the remaking of the Chinese administrative state, but, equally and increasingly, the emerging movement for self-protection of society has begun to push the state to pay more attention to social needs and values.

However, as the two movements move toward opposite directions and for conflicting interests, administrative reforms in China have had to face the challenge of making a balance among conflicting demands and requirements, leading to a deep-seated institutional strain. With tremendous unprecedented challenges ahead, the rebuilding of the Chinese administrative state will be more demanding in the future.

Polanyi ([1944]1957, 223-36) suggested that democratic politics possibly provided a way, though not the best one, to resolve this clash of interests. By subordinating the market to democratic politics, social justice can be achieved in a prosperous market. On the one hand, the economy will still be organized according to the logic of markets, generating sufficient material wealth for society. Democratic politics, on the other hand, will empower the people in the society with expanded rights and channels for influencing policymaking to protect society and nature from economic dangers.

It is this point of analysis that well exposes the biggest limitation inherent in the Chinese administrative reforms. Of the six rounds of reform in the last three decades, only the 1988 reform touched on the relationship between politics and administration by proposing the separation of the government from the Party. One fundamental but often neglected common feature throughout all other administrative reforms has been the prerequisite that they cannot alter the basic fabric of the Leninist Party state. It seemed the Chinese leadership believes that political issues relevant to democratic accountability could be solved by a variety of totally technical administrative reforms. So far so successful has been this strategy. However, easy years had gone. In face of the conflict of interests associated with the double movements, the rebuilding of the Chinese administrative state does need a reconfiguration of the relationship between politics and administration, and fundamentally between the state and citizenries. While the vision for rearranging the relationship between state and economy is clear-to limit and 
rationalize the government's intervention in economy in order to ensure a necessary economic autonomy-the vision of the ultimate relationship between state and society as well as between politics and administration is still vague. In the end it will require a form of political democracy. This therefore suggests that the remaking of the Chinese administrative state still has a long way to go. Admittedly, it is here the framework developed in this paper reaches its own limitations. For a better understanding of China's administrative reform and the challenges ahead, in addition to the perspective of double movements, one must consider the incentive structure of the Chinese Communist Party.

\section{REFERENCES}

Brettell, A. (2007). China's pollution challenge: The impact of economic growth and environmental complaints on environmental and social outcomes. In S. Guo and B. Guo (Eds.), Challenges facing Chinese political development (pp. 15593). New York: Lexington Books.

Brødsgaard, K. E. (2002). Institutional reform and bianzhi system in China. China Quarterly, 170: 361-82.

Burns, J. P. (1993a). Administrative reform in China: Issues and prospects. International Journal of Public Administration, 16(9): 1345-69.

(1993b). China's administrative reforms for a market economy: Summary. Public Administration and Development, 13(4): 345-60.

. (2001). Public sector reform and the state: The case of China. Public Administration Quarterly, 24(4): 419-36.

. (2003). "Downsizing" the Chinese state: Government retrenchment in the 1990s. The China Quarterly, 175: 775-802.

. (2007). Civil service reform in China. OECD Journal on Budgeting, 7(1): 1-25.

Cai, Y. (2007). Civil resistance and rule of law in China. In E. Perry and M. Goldman (Eds.), Grassroots political reform in contemporary China (pp. 174-95). Cambridge, MA: Harvard University Press.

Chan, C. K., K. L. Ngok, \& D. Phillips. (2008). Social policy in China: Development and well-being. Bristol: The Policy Press.

Chan, H. S., \& K. W. Chow. (2007). Public management policy and practice in western China. The American Review of Public Administration, 37(4): 479-98.

Chan, H. S., \& S. Li. (2007). Civil service law in the People's Republic of China: A return to cadre personnel management. Public Administration Review, 67(3): 383-98. 
Chang, M. H. (1998). The labors of Sisyphus: The economic development of communist China. New Jersey: Transaction Publishers.

Chao, L., \& J. Leow. (2008). China's food-safety chief resigns under pressure. Wall Street Journal, September 23.

Chen, A. (2002). Socio-economic polarization and political corruption in China: A study of the correlation. Journal of Communist Studies \& Transition Politics, 18(2): 53-74.

Chen, J., W. Hou, \& S. Jin, (2008). A review of the Chinese Gini coefficient from 1978 to 2005. Paper presented at the 2008 Chinese (UK) Economic Association annual conference.

Chen, Z. (2007). Has state ownership caused more inequality in China? The political economy of income opportunities. In X. Liu (Ed.), Institutional development and harmony (pp. 29-64). Hong Kong: Ming Bao Press.

Chen, Z., Z. Wu, \& S. Xie, eds. (2000). The extent of marketization of economic systems in China. Hauppauge, NY: Nova Science Publishers.

Dickson, B. J., \& C.-m Chao. 2001. Introduction: Remaking the Chinese state. In C.-M. Chao and B. J. Dickson (Eds.), Remaking the Chinese state: Strategic, society, and security (pp. 1-16). New York: Routledge.

Fan, C., \& H. I. Grosssman. (2001). Incentives and corruption in Chinese economic reform. Journal of Policy Reform, 4(3): 195-206.

Goldman, M. (2005). From comrade to citizen: The struggle for political rights in China. Cambridge: Harvard University Press.

Gong, T. (2002). Dangerous collusion: Corruption as a collective venture in contemporary China. Communist \& Post-Communist Studies, 35(1): 84-102.

. (2006). Corruption and local governance: The double identity of Chinese local governments in market reform. Pacific Review, 19(1): 85-102.

Gries, P., \& Rosen, S. (2004). Introduction: Popular protest and state legitimation in 21st century China. In P. Gries and S. Rosen (Eds.), State and society in 21st century China: Crisis, contention, and legitimation (pp. 1-23). New York: Routledge Curzon.

Hao, Y. (1999). From rule of man to rule of law: The unintended consequences of corruption in China in the 1990s. Journal of Contemporary China, 8(22): 405-23.

Ho, P. (2006). Trajectories for greening in China: Theory and practice. In P. Ho and E. B. Vermeer (Eds.), China's limits to growth (pp. 1-26). Malden: Blackwell Publishing.

Howell, J., \& J. Pearce. (2001). Civil society and development: A critical exploration. Boulder, CO: Lynne Rienner Publishers.

$\mathrm{Hu}$, A. (2007). Economic and social transformation in China: Challenges and opportu- 
nities. London: Routledge.

Hua, J. (2008). The interpretations of institutional restructuring of the State Council. Beijing: National People's Congress.

Kettl, D. (2005). The global public management revolution: A report on the transference of governance, 2nd ed.. Washington, DC: Brookings Institution Press.

Lan, Z. (1999). The 1998 administrative reform in China. Asian Journal of Public Administration, 21(1): 29-54.

Larsson, T. (2006). Reform, corruption, and growth: Why corruption is more devastating in Russia than in China. Communist \& Post-Communist Studies, 39(2): 265-81.

Leonard, M. (2008). What does China think? London: Harper Collins Publishers.

Lewis, J., \& L. Xue. (2003). Social change and political reform in China: Meeting the challenge of success. The China Quarterly, 176: 926-42.

Li, S., \& X. Yue. (2007). Income distribution in China: Its current state, causes, and policies. In X. Liu (Ed.), Institutional development and harmony (pp. 1-28). Hong Kong: MingBao Press.

$\mathrm{Lu}, \mathrm{X}$. (2000). Booty socialism, bureau-preneurs, and the state in transition: Organizational corruption in China. Comparative Politics, 32(3): 273-94.

Lum, T. (2006). Social unrest in China. Washington, DC: Congressional Research Service.

Luo, G. (1998). The interpretations of institutional restructuring of the State Council. Beijing: National People's Congress.

Luo, X., \& N. Zhu. (2008). Rising income inequality in China: A race to the top. Washington, DC: The World Bank.

Ma, J. (2008). State rebuilding in China since the economic reform. Paper presented to The International Symposium on American Progressive Era Reform and Its Implications for China (Guangzhou, P. R. China, June 15-16 2008).

Ma, Q. (2006). Non-governmental organizations in contemporary China: Paving the way to civil society? London: Routledge.

Manning, N., \& N. Parison. (2003). International public administration reform. Washington, DC: The World Bank.

Meagher, P. (2005). Anti-corruption agencies: Rhetoric versus reality. Journal of Policy Reform, 8(1): 69-103.

Mol, A. P. J. (2006). Environment and modernity in transitional China: Frontiers of ecologic modernization. In P. Ho and E. B. Vermeer (Eds.), China's limits to growth (pp. 27-54). Malden: Blackwell Publishing.

Morton, K. (2005). The emergence of NGOs in China and their translational linkage: Implications for domestic reform. Australian Journal of International Affairs, 59(4): 519-32. 
Ngok, K., \& G. Zhu. (2007). Marketization, globalization and administrative reform in China: A zigzag road to a promising future. International Review of Administrative Sciences, 73(2): 217-33.

Pei, M. (2006). China's trapped transition: The limits of developmental autocracy. Cambridge: Harvard University Press.

Perry, E., \& M. Selden, eds. (2000). Chinese society: Change, conflict and resistance, 2nd ed. London: Routledge.

Polanyi, K. ([1944] 2001). The great transformation: The political and economic origins of our time. Boston: Beacon Press.

Qiao, J., \& Jiang, Y. (2005). Analysis of labor disputes and mass incidents in marketization process. In X. Ru, X. Lu, P. Li, P. Huang \& J. Lu (Eds.), 2005 Blue book of China's society (pp. 296-314). Beijing: Social Science Academic Press (China).

Riskin, C. (1997). Social development, quality of life and the environment. In E. Bliney (Ed.), Crisis and reform in China (pp. 89-110). New York: Nova Science Publishers.

Shieh, S. (2005). The rise of collective corruption in China: The Xiamen smuggling case. Journal of Contemporary China, 14(42): 67-91.

Solinger, D. J. (2001). Clashes between reform and opening. In C.-m. Chao and B. J. Dickson (Eds.), Remaking the Chinese state: Strategies, society, and security (pp. 103-31). London: Routledge.

. (2004). The creation of a new underclass in China and its implications. Paper presented at the POSRI International Forum on China's Development: Key Challenges for China's Sustained Growth.

Sun, Y. (2005). Corruption, growth, and reform: the Chinese enigma. Current History, 104(683): 257-63.

Tam, W., \& D. Yang. (2007). Food safety and the development of regulatory institutions in China. In D. Yang (Ed.), Discontented miracle: Growth, conflict, and institutional adaptations in China (pp. 161-91). Singapore: World Scientific.

Tsao, K. K., \& J. A. Worthley. (1995). Chinese public administration: Change with continuity during political and economic development. Public Administration Review, 55(2): 169-74.

Wang, S. (2006). The pattern of agenda setting in Chinese public policy. Chinese Social Science, 5: 86-123.

(2007). From economic policy to social policy: The historic transformation in China's public policy. In J. Yue \& W. Guo (Eds.), Chinese public policy review (vol. 1, pp. 29-45). Shanghai: Century Publisher.

Wang, X. (2004). Marketization in China: Progress and prospects. In R. Garnaut and L. Song (Eds.), China: Is rapid growth sustainable? (pp. 118-36). Canberra: 
Asia Pacific Press at the Australia National University.

Wang, Z. (2003). The interpretations of institutional restructuring of the State Council. Beijing: National People's Congress.

Wedeman, A. (2004). The intensification of corruption in China. China Quarterly, 180: 895-920.

Weston, T. B. (2004). The iron man weeps: Jobless and political legitimacy in the Chinese rust belt. In P. Gries and S. Rosen (Eds.), State and society in 21st century China: Crisis, contention, and legitimation (pp. 67-86). New York: Routledge Curzon.

White, G., J. Howell, \& X. Shang. (1996). In search of civil society: Market reform and social change in contemporary China. Oxford: Clarendon Press.

Woo, W. T. (2007). The origins of China's quest for a harmonious society. In R. Sanders and Y. Chen (Eds.), China's post-reform economy: Achieving harmony, sustaining growth (pp. 15-29). London: Routledge.

World Bank. (2005). 2005 world development indicator. Washington, DC: World Bank.

Worthley, J. A., \& K. K. Tsao. (1999). Reinventing government in China. Administration \& Society, 31(5): 571-87.

Wright, T. (2004). The political economy of coal mine disasters in China: "Your rice bowl or your life." The China Quarterly, 179: 629-46.

Yang, D. (2001). Rationaling the Chinese state: The political economy of government reform. In C.-M. Chao and B. J. Dickson (Eds.), Remaking the Chinese state: Strategies, society, and security (pp. 19-45). London: Routledge.

. (2004). Remaking the Chinese leviathan: Market transition and the politics of governance in China. Stanford, CA: Stanford University Press.

Yang, K. (2004). China's 1998 administrative reform and New Public Management: Applying a comparative framework. International Journal of Public Administration, 30(12): 1371-92.

Yu, J. (2007). The disturbance incidents and governance crisis in China. Retrieved 27 Feb, 2009, from http://www.chinaelections.org/NewsInfo.asp?NewsID=118361.

Zheng, Y. (2004a). Globalization and state transformation in China. Cambridge, UK: Cambridge University Press.

. (2004b). Interest representation and the transformation of the Chinese Communist Party. In K. E. Brødsgaard and Y. Zheng (Eds.), Bring the party back in: How China is governed (pp. 269-301). Singapore: Marshall Cavendish International. 